\title{
APPRECIATING COMPLIANCE WITH INTERNATIONAL ENVIRONMENTAL LAW TREATIES: LESSONS FROM A DEVELOPING COUNTRY - MALAYSIA*
}

\author{
Azmi Sharom**
}

\begin{abstract}
"[A] World Order based on the Rule of Law thinly hides from sight the fact that social conflict must still be solved by political means and that even though there may exist a common legal rhetoric among international lawyers, that rhetoric must, for reasons internal to the ideal itself, rely on essentially - political - principles to justify outcomes to international disputes." 1
\end{abstract}

In a world where international law is often breached by those with the power or the nerve, it would be tempting to subscribe to the Realist view above, then compliance with international law would appear to be merely an ideal of the naïve. However, is such pessimism justified? In this article, it will be shown that such a cynical approach is not entirely accurate and that despite the recalcitrant acts of the few, there is still reason to strive towards the achievement of better compliance with international law. There is a case to be made in support of compliance as a valid and important concern with sound theories to encourage greater adherence to the principle. Here, the focus shall be on international environmental law.

\section{IS CYNICISM JUSTIFIED?}

At the core of Realist argument is the fact that international law can be separated neither from politics nor from power play. The principle of State sovereignty means that the very nature of international law making (treaties, for example) is a reflection of State will. There is no distinction therefore between what a State wants and what they choose with which to govern themselves. Although this may provide the

\footnotetext{
* This paper is drawn from a Ph.D. thesis by A. Sharom, entitled "Compliance with International Environmental Law: Three Malaysian Case Studies”, University of London, 2002.

** Lecturer in Law, University of Malaya.

1 M. Koskenniemi, "The politics of international law", 1 EJIL 4 (1990), at 7.

Asian Yearbook of International Law, Volume 10 (B.S. Chimni et al., eds.)

(C) 2005 Koninklijke Brill NV. Printed in The Netherlands, pp. 57-93.
} 
semblance of a legal order, in fact it merely veils the political will and force of the State players. Realists would argue that the study of compliance and the theories with which to improve it is a waste of time. This is because States comply not because of treaty obligations per se, but because of political or economic reasons. Therefore, no matter what a treaty contained, this would make no difference to State behaviour because the State would ultimately do what is best for its interest.

It is true that self-interest governs much of international law. The making of treaties is after all a reflection of State will. Furthermore, even domestic law making in a democratic society is to a certain extent a reflection of the will of its subjects. The issue here is whether, although politics do play a major role in international law, the latter should then be viewed with total cynicism? Should cynicism then colour the discussion of compliance even once the laws have been made? Overt pessimism implies that since international law ultimately, regardless of the ratification of treaties and the like, will always take a back seat to self-interest, compliance therefore happens as an accident rather than as a legal obligation.

However, the realpolitik position, above, where the concept of law takes a back seat to political realities, does have one glaring weakness. A subtle argument is put forward by Oppenheim, ${ }^{2}$ who says about the precious State sovereignty that nations guard so carefully,

"(I)t is only by reference to a higher legal rule in relation to which they are all equal, that the equality and independence of a number of sovereign States can be conceived. Failing that superior legal order, the science of law would be confronted with the spectacle of some sixty sovereign States, ${ }^{3}$ each claiming to be the absolute highest and un-derived authority".

In short, in order to exist in the form that they wish, States already have to make a concession to the idea of law - without which the present system, imperfect as it is, would simply crumble.

Furthermore, there are writers such as Oran Young who dispute that States act purely on political self-interest alone. Young devised a method through which to examine the efficiency of international institutions or regimes (this would include treaty regimes) to prove that realist ideology is not without its flaws. ${ }^{4}$ According to this test, one has to look at what have been described as "hard cases". These are situations where:

a. One or more prominent members of the group are predisposed to dislike the decisions of the international institution;

\footnotetext{
${ }^{2}$ Quoted in I. Brownlie, Principles of Public International Law, $4^{\text {th }}$ edn., Oxford: Clarendon Press, 1990 , at 33.

3 This was written in 1938.

4 O.R. Young, "The effectiveness of international institutions: hard cases and variables", in J.N. Rosenau and E.O. Czempiel, (eds.), Governance Without Government: Order and Change in World Politics, Cambridge University Press, 1992.
} 
b. It is comparatively easy to violate the rules of the international institution in such a way that it is hard to prove that the breach occurred, and

c. Ongoing changes in international society raise doubts about the relevance or underpinnings of the regime.

If the international institution can survive a situation with one or all of the above characteristics then it can be deemed to be working; it does in fact change behaviour despite obstacles, therefore it is not merely the plaything of States' wills. An example is the Whaling Convention (1946). Despite the changes to society and the regime (from a mere regulatory approach to an anti-whaling sentiment), the opposition of key members to any real control of whaling (of Norway and Japan, in particular) and the difficulties of enforcement, the Convention still managed to adopt the 1986 moratorium banning whaling and put pressure on so-called "scientific whaling".

However, another view veers away from simple one-upmanship. Chayes and Chayes argue that there is actually no empirical evidence to indicate that States comply only when it is in their interest to do so; this in turn, conversely, suggests that they comply even when it is not in their interest to do so. ${ }^{5}$ Such "evidence" is merely anecdotal and there is no statistical or empirical data to support either view. Instead, they imply that these two opposing points of view are "background assumptions". The method with which one approaches compliance would thus depend on the type of assumption being used.

Chayes and Chayes go on to argue that Realist assumptions are not helpful when attempting to study ways with which to improve compliance. The Realist assumption is that a State's primary motivation is, they say, economic and military in nature. Any improvement in compliance would therefore require action along the lines of economic or military sanctions. Both methods are expensive, hard to mobilise, of doubtful efficacy, and probably politically unpopular. On the other hand, using a background assumption that States will generally comply, regardless of the selfinterest of each, is more illuminating when attempts are made to devise a framework for understanding and improving compliance.

Other writers have also reached conclusions that support the approach of Chayes and Chayes. Mitchell's study on the regimes governing international oil pollution found that parties to a treaty not only abide by treaty provisions; by and large, they do so even at a significant cost to themselves. ${ }^{6}$ Sands argues that the sheer bulk of international environmental dispute settlement in various fora (not necessarily the International Court of Justice) has meant that Realists such as Koskenniemi are no longer relevant, for greater dispute settlement efforts through activities such as

\footnotetext{
5 A. Chayes and A.H. Chayes, "On compliance", 47 International Organization 175-205 (Spring 1993).

${ }^{6}$ R.B. Mitchell, Intentional Oil Pollution at Sea: Environmental Policy and Treaty Compliance, Massachusetts: The MIT Press, 1994.
} 
arbitration reflects a greater faith not only in the international dispute settlement mechanisms but also in the laws with which that system is to apply.

Furthermore, it is submitted that States do not as a general rule ratify treaties in order not to comply. In their article "On Compliance" Chayes and Chayes argue that the voluntary and consensual nature of treaties means that States become party to them because it is believed by these States that it is in their interest to do so. ${ }^{8}$ The treaty-making process involves a great deal of discussion and negotiations at the national, regional, and international levels. During these discussions the specialized wishes of a State can by and large be accommodated. These wishes can be pushed forward either individually or collectively. It is true that the political realities of the world mean that stronger States have a greater influence on the treaty-making process. For example, the United States by itself almost put a stop to the United Nations Convention on the Law of the Sea despite ten years of negotiations. However, using the same treaty as an example, the relatively weak coalition of land-locked States managed to have their interests represented and reflected in the treaty despite being small players amongst the sea-going nations. ${ }^{9}$ In other words, the treaty-making process allows through its participatory elements for checks and balances to occur. This ultimately leads to a situation where the treaty is a compromise of interests. It may result in a weak treaty - yet a weak treaty is, arguably, better than no treaty at all. Besides, a treaty should be an organic entity, constantly growing, changing and evolving; thus, it has the potential to become stronger.

Taking these factors into consideration Chayes and Chayes argue that two factors can be concluded: firstly, that States will not take part in lengthy and expensive negotiations in order routinely to violate treaty provisions; secondly, that if there is no compliance, then it is because the treaty does not accurately reflect the needs and wishes of States, rather than because non-compliance is a deliberate action on their part. ${ }^{10}$

\section{COMPLIANCE THEORY}

Working therefore on the premise that compliance matters, what follows is a study of compliance theory. To summarize: compliance theory is the body of ideas and principles that aim towards the improvement of compliance with international treaties. Before compliance theory is examined, however, there should first be a discussion of the definitions of 'compliance'.

\footnotetext{
7 P. Sands, "Compliance with international environmental obligations: existing international legal arrangements", in J. Cameron, J. Werksman and P. Roderick, (eds.), Improving Compliance with International Environmental Law, London: Earthscan Publications, 1996, at 81.

8 See n. 5, at 179-180.

9 See especially Part X of the United Nations Convention on the Law of the Sea that is entitled "Right of Access of Land-Locked States to and from the Sea and Freedom of Transit".

${ }^{10}$ See n. 5, at 183.
} 


\subsection{Definition of 'compliance'}

'Compliance' is defined in the Ninth Edition of the Concise Oxford Dictionary as "the act or an instance of complying; obedience to a request, command, etc.". In short, compliance, in its common, everyday meaning, is the act of obeying, of doing what one is told to or has agreed to. For the purposes of this article, though, there has to be somewhat more clarity than that. What is meant, after all, by such terms as "obeying" and "obedience"? How are these terms relevant when treaty obligations are addressed? When discussing compliance issues in international law as to the parameters of the discussion have to be absolutely certain. This is important because there can be many interpretations over the implications of compliance.

Firstly, compliance has to be distinguished from mere "implementation". Implementation consists of the formal legislation or regulations adopted by countries for them to comply with treaties. According to Brown Weiss and Jacobson:

"Implementation refers to measures that States take to make international accords effective in their domestic law. Some accords are self-executing; that is, they do not require national legislation to become effective. But most international accords require national legislation or regulations to become effective". ${ }^{11}$

They go on to say:

"Compliance goes beyond implementation. It refers to whether countries in fact adhere to the provisions of the accord and to the implementing measures that they have instituted. The answer cannot be taken as given even if laws and regulations are in place. Measuring compliance is more difficult than measuring implementation. It involves assessing the extent to which governments follow through on the steps that they have taken to implement international accords. In the end, assessing the extent of compliance is a matter of judgment.

Compliance has several dimensions. Treaties contain specific obligations, some of which are procedural, such as the requirement to report, and others that are substantive, such as the obligation to cease or control an activity. In addition, preambles or initial articles in treaties place these specific obligations in a broad normative framework, which we refer to as the "spirit of the treaty". ${ }^{12}$

This definition is slightly different from one offered by R.B. Mitchell, ${ }^{13}$ who defines 'compliance' as "behaviour that conforms to a treaty's explicit rules". ${ }^{14}$ An example of such behaviour would be the adoption of national implementation measures, such as the passing of relevant legislation if existing legislation is in-

11 E. Brown Weiss and H.K. Jacobson (eds.), Engaging Countries: Strengthening Compliance with International Environmental Accords, MIT Press, 1998, at 4.

12 Brown Weiss and Jacobson, n. 11, at 4.

13 R.B. Mitchell, "Compliance theory: an overview”, in Cameron, Werksman and Roderick, n. 7.

14 Emphasis added. 
sufficient. In this definition, note the emphasis on the "explicit rules" of a treaty. This definition excludes two methods of examining compliance, and these are:

a. Examining the treaty as a whole when discussing compliance, as this definition is concerned only with specific provisions. For example, if a treaty were to have 100 articles or sections, the study of compliance according to Mitchell would be a matter of examining each and every article (or part) and seeing whether they are individually being complied with or not, without being concerned with whether the treaty as a whole is being complied with. ${ }^{15}$

b. Examining the role of the subtext, general norms or "spirit" of the treaty and the intentions of the parties that can be deduced from sources such as the preamble and the travaux preparatoires.

This is a rather technical method of study. Mitchell defends his approach as being necessary for the purposes of empirical research. It is easier, after all, to gauge compliance at this very objective level. Studying a treaty as a whole can also be counter-productive. Too much time may be spent pedantically pointing to instances of non-compliance with particular provisions as being indicative of treaty failure. This is especially true in the light of the work done by Chayes and Chayes, who argue that non-compliance with a few provisions need not necessarily mean that the treaty has failed. ${ }^{16}$ Compliance can never be perfect: what is sought is substantial or acceptable compliance; therefore, any insistence on the faultless compliance with every single article of a treaty would be unrealistic. In the words of Mitchell:

\begin{abstract}
"Evaluating compliance against treaty provisions also makes more sense than speaking of compliance with the treaty as a whole. Parties often comply with some treaty provisions while violating others. Within a nation, different actors - governments, industry and non-governmental organisations (NGOs) - may well be responsible for implementing different treaty provisions. To speak of 'treaty compliance' therefore loses valuable empirical information by aggregating violation of one provision compliance with another. It also deserves mention that measuring compliance by strict reference to legal standards suggests that compliance is binary, either one complies or one violates: in fact[,] treaties can induce considerable beneficial behavioural change that either falls short of actual compliance, strictu sensu, or goes beyond minimum treaty requirements". ${ }^{17}$
\end{abstract}

There are other benefits with Mitchell's approach, which was also adopted by Sands. ${ }^{18}$ The sheer subjectivity of concepts such as "intentions" can lead to a separate quagmire of debate within which the researcher can get bogged down to such an extent that the primary questions regarding compliance per se gets lost in

\footnotetext{
See n. 13, at 5-6.

See n. 5.

See n. 13, at 6.

8 See n. 7.
} 
the secondary questions and interpretations as to what constitutes "intentions", and other similarly theoretically challenging discussions. Admittedly, even specific provisions are open to interpretation. However, the constant interpretation and reinterpretation of provisions is a normal part of treaty-based law. This process is to be expected and is fundamentally different from examining a treaty in the light of more intangible concepts such as "intention". The former involves the study of rules that are determined and laid out clearly on paper while the latter depends on more circumstantial authorities.

The problem with this definition is that it is possible that any implementing action done by a State may be deemed as compliance. This is clearly not good enough. For implementation to have meaning, that is to say, if it can be deemed as compliance, then there is a need to assess the extent to which governments ensure that their implementation measures sufficiently meet the objectives of the treaty. Surely it cannot be deemed compliance if a government establishes a monitoring body as demanded by the treaty, but then fails to staff it with qualified people (such detail is normally not included in treaties, but it is certainly implied). It is therefore insufficient merely to study treaty provisions and their specific demands: one must look also at the "spirit" behind those demands. 19

Given that the purpose of this study is determining ways of improving compliance, a certain degree of subjectivity can enter into the definition used. This is similar to the approach taken by Edith Brown Weiss and Harold K. Jacobson (see above) and for the purposes of this article there will be a combination of both these definitions. The common sense of the Weiss and Jacobson approach will provide the basis, while certain elements of Mitchell's definition, in particular the aspect of emphasising individual treaty provisions rather than the treaty as a whole, will also be used. In short, 'compliance' shall be defined as: "The actions which conform to the explicit rules and the broad norms or spirit of a treaty".

\subsection{Compliance distinguished from effectiveness and enforcement}

Two further points of definition needs to be made, namely, to distinguish the term "compliance" from the terms "effectiveness" and "enforcement". Effectiveness is related to compliance, yet is not identical with it. Compliance with a treaty need not necessarily mean that it is effective and similarly, any effectiveness need not be found merely because of compliance. For example, there may be good compliance with a treaty regarding international trade in a particular endangered species. However, due to domestic consumption of that species, the problem that the treaty was designed to address, the prevention of extinction, is not effectively met. Conversely, a country

19 It should be noted that one of the reasons for this disparity in approach is because Mitchell's definition was designed with the specific intention of maximising the empirical element of his research. This is due to the fact that one of the tenets of his argument is that treaties change behaviour; in other words, that compliance is the result of treaty law. It constitutes a challenge to realist thinking, which assumes that compliance is accidental and independent of the treaty. 
may not be in compliance with a pollution treaty, but due to other factors, for example, an economic collapse, there are left no factories that may pollute. This study is concerned not with the effectiveness of international environmental law per se, because effectiveness can be influenced by factors other than the treaty. Thus, in order to determine how compliance can be improved, the study needs to concentrate on compliance itself., As a general rule, furthermore, it can be said that greater compliance should lead to greater effectiveness. ${ }^{20}$

The term 'enforcement' can also be confused with compliance, but there is an important distinction: compliance means that a duty has been carried out, while enforcement comes into play only if that duty was not carried out - in other words, if there was no compliance. Of course there is a relationship between the two, for tighter enforcement should encourage greater compliance, but, as can be seen, they are rather different. The two terms are not interchangeable and should be kept separate.

Enforcement is, however, seen as the normal method through which to elicit compliance. Respected international environmental law textbooks, such as Birnie and Boyle's International Law and the Environment ${ }^{21}$ and Philippe Sands' Principles of International Environmental Law Vol. $1^{22}$ both have chapters on compliance and both focus primarily on enforcement measures, i.e. what can be done when compliance has not occurred. There is no denying the importance of this approach. It is vital to ensure that enforcement measures are robust and ever expanding [to meet growing needs]. That is not, though, within the scope of this article. Moreover, it is submitted that compliance is of greater importance than enforcement, particularly with regard to the environment: once enforcement measures have to come into play, generally, it can safely be said that the damage has already been done. In the field of the environment, this is not the ideal situation. It is more pertinent to consider the fact that international dispute settlement (the usual form of enforcement measures) can take a long time to conduct. Furthermore, the traditional remedies of damages may not be able to put right the environmental damage done. No amount of money can, for example, bring back to life an extinct species or a destroyed ecosystem.

\subsection{Why states comply and why they do not}

In order to examine compliance there has to be an understanding of the reasons why States comply and, conversely, why they do not. If this can be established then, theoretically, improving compliance becomes a matter of encouraging the positive and limiting the negative which, as can be seen later, is what compliance theory tries to achieve.

\footnotetext{
20 Brown Weiss and Jacobson, n. 11, at 5.

${ }^{21}$ Patricia Birnie and Alan Boyle, International Law and the Environment, Oxford: Oxford University Press, 1992.

${ }^{22}$ Philippe Sands, Principles of International Environmental Law, Vol. 1, Manchester: Manchester University Press, 1994.
} 
In their book Engaging Countries: Strengthening Compliance with International Environmental Accords, Brown Weiss and Jacobson identify several factors that could influence a State's compliance. ${ }^{23}$ These factors take into account the treaty itself as well as considerations beyond the actual document.

With regard to the treaty, consideration has to be given to the actual treaty-making process. This would include factors such as who drafted the treaty, the form taken by negotiations, and the depth and extent of agreement. One can reason that the greater a nation's involvement in the process and the more its views were taken into consideration, the greater is the likelihood that the State would be compliant. This idea matches the one put forward by Chayes and Chayes above: that States become involved with the treaty process because they wish for it to achieve their objectives.

The nature of the treaty provisions could also play a part in compliance, whether they are substantive or procedural, and whether they are specific or vague. The sort of compliance mechanism that exists within the treaty will, of course, have an important role to play. It follows that the clearer are a treaty's obligations and the stronger is its compliance mechanism, compliance is more likely to occur.

The way that a treaty treats non-members is another factor to be considered. That is, to ask whether member States may continue to deal with non-member countries or whether there is a bar against their doing so. If a government is of the opinion that joining a treaty will offer no differences from when they are not a party, this perspective may prove to be a disincentive to joining. Conversely, if a State believes that by being a party to and complying with the treaty there is to be gained a definite advantage that to remain outside the regime would not offer, then it will be an incentive for joining and for complying with the treaty obligations.

Compliance-influencing factors beyond the treaty proper can be further divided into two types. Firstly, there is the international environment, by which is meant the action and attitude of other States towards the treaty. Is there generally a good degree of compliance? Is there pressure applied among States for fellow Members to comply? Is the practice of 'free riding', i.e., when party members do not comply yet enjoy the benefits of the treaty nonetheless because sufficient numbers do comply, prevalent? Furthermore, the relationship between the States and international organizations related to the treaty (for example, the Secretariat) can be a significant factor. It is submitted that if Member States and any relevant international organization were to behave in a positive and pro-active manner, this would induce greater compliance.

The second question concerns factors at the national level. A country with a strong economy and a sound democratic system would, fundamentally, be more likely to comply. This is because it would be able to afford the necessary expenditure to comply and its citizens would have avenues with which to apply pressure on the government if it failed to do so. However, the idea that democracy automatically equals better compliance cannot be relied on. Vogel and Kessler argue that greater democracy does not necessarily mean wider environmental compliance.

23 Brown Weiss and Jacobson, n. 11, at 7. 
"In the former Soviet Union, democratisation reduced national compliance with some international environmental agreements. What democratisation does offer citizens is a greater voice in shaping a wider array of public policies, including environmental regulation. If the citizens of democratic or relatively democratic nations strongly support the objectives of the environmental treaties their government has signed, as appears to be the case in the United States and Northern Europe, compliance is likely to be enhanced. On the other hand, if they value other objectives, such as profit from the sales of endangered species or inexpensive refrigeration, then compliance is likely to prove more difficult." 24

In his book Intentional Oil Pollution at Sea, Mitchell offers further analysis on the sources of compliance and non-compliance. Whilst he does not take a Realist viewpoint, he does acknowledge the political aspects of treaty behaviour and these are reflected in his conclusions. Many States comply with treaty law, for example, simply because it is good for them or because there can be no loss arising from their compliance. It is possible that a State already has such stringent laws on the environment within its own jurisdiction that treaty compliance entails no significant change in behaviour. It does, howeve,r give them a moral high ground over non-party States and [influence the] legitimization of policy and legislation at the national level. It is also possible that States comply because the treaty provisions themselves are so vague that even inaction would not be seen as non-compliance, or the treaty is attempting to control behaviour that is beyond the ability of States to carry out. ${ }^{25}$

However, there are also sources of compliance that do not fall conveniently within the Realist-type explanations. Non-compliance may have an unknown effect on the future of the treaty and on future treaty relationships. Such an uncertainty could act as a deterrent to non-compliance. This fear of the unknown is related to another source of compliance: that once the rules of a treaty are set in place and the bureaucracy established, it might actually be difficult to stop complying in order to violate a condition. That is to say, it becomes easier simply to comply, as compliance can be habit forming; also, decision-making becomes so much simpler when following a set of established rules and procedure. ${ }^{26}$

Furthermore, treaties can cause publicity. Non-compliance that is highly publicised may have a serious shaming effect on the offending State. This goes hand in hand with the next source of compliance: political pressure. Treaties provide a convenient rallying ground for environmental lobbyist and activist groups on which they can focus their pressure on States at a domestic and international level, giving their campaign legal weight and authority, and making it hard for States to be inactive since they have already agreed to a particular course of action.

\footnotetext{
${ }^{24}$ D. Vogel and T. Kessler, "How compliance happens and doesn't happen domestically", in Brown Weiss and Jacobson, n. 11, at 34.

${ }^{25}$ For example, nodule mining in the deep-sea bed under United Nations Convention on the Law of the Sea as governed by Article 151 .

26 A point also supported by Chayes and Chayes, n. 5 .
} 
Compliance may also occur because of what Mitchell terms 'interdependent selfinterest'. This is a situation where compliance is seen by States as being an option preferable to non-compliance because it encourages other States to comply; in turn, this will improve the situation for a complying State. Therefore, to violate treaty provisions or not to comply brings very little good, ultimately. Unfortunately, interdependent self-interest can encourage the problem of 'free riding'.

Apart from 'free riding', other reasons why States may not comply can range from the relatively "innocent" to the more cynical. "Innocent" non-compliance would be due to problems such as incapacity, where a State cannot afford to comply or does not have the necessary tools (technology, trained staff, or institutional mechanisms) for compliance, and inadvertence where a State tried in good faith yet failed to comply, for whatever reason (usually associated with non-capacity).

Vogel and Kessler state that making laws and directives without taking into account the capacity of regulatory bureaucracies to implement them would lead to poor compliance. For example, the American Environmental Protection Agency was given too much to do in too little time, leading to long delays before legislative initiatives took concrete form. If such problems arise in a country as wealthy as the United States, then such requirements would be even more problematic in developing nations. However, as a general rule, Vogel and Kessler assert, "compliance tends to be greatest in nations whose government bureaucracies are the most competent and powerful.", 27

There is also the possibility that States have acted cynically in signing and/or ratifying a treaty and had no intention, in the first place, of complying. A State may sign or even ratify a treaty for many self-serving reasons, such as the positive publicity of being part of a treaty, or even to show political support to allies by signing a treaty as a favour to them. It is also possible that the State had never intended to comply. This could be because it realizes that enforcement measures are too weak to be used effectively against them; also, value systems might differ, where the State agrees in principle with the aims of the treaty but in practice finds other, more important, matters that require attention. Needless to say, there is a plethora of reasons why States do not comply. The issue now to be addressed is to ask what can be done about non-compliance.

In the face of non-compliance the international community has traditionally seen two types of action that may be taken in order to elicit compliance. These are, on the one hand, positive inducements, implying financial and technological help along with the provision of educational aid and training; on the other hand, negative sanctions include taking enforcement measures; the shaming of offending States by exposure to the press or at least to the Conference of Parties; the forcing of compliance by powerful States, and reciprocity where non-compliance by State A would result in a similar action by State B (this is useful only in small multilateral or bilateral treaties). Some negative sanctions are perhaps particularly unattractive to enforce, and may even lead to counter-productive results. The thought of a powerful

27 Vogel and Kessler, n. 24, at 22-23. 
State from the North 'punishing' a small State from the South may in itself be enough to raise Third World hackles to the point that the actual issues become confused; attention may be directed away from the environmental concern at hand. It is, after all, only wealthy and powerful States which have the strength to take such action, often unilaterally. As it stands, only the United Nations Charter and the Organization of American States Charter allow for the use of harsh negative sanctions, be they economic or military, in order to force compliance. Both methods come at a high cost, administratively, economically and politically.

Taking into account the reasons why States do and do not comply, and considering the limitations of more "traditional" methods of eliciting compliance, it is submitted that it is possible to design a theory to encourage the creation of a system that actually supports compliance with treaties without the need for confrontational methods of enforcement.

\subsection{Compliance through a system of management}

Supporters of compliance theory do not dispute the Realist argument that external factors can influence compliance; their differing opinion is based on the belief that treaty provisions can have an effect as well. Whether the provisions of a treaty can induce compliance depends on the treaty's own compliance system. A compliance system consists of the provisions within the treaty itself that determine the methods with which compliance can be induced. Chayes and Chayes describe the system as compliance through management.

\footnotetext{
"We believe that effective compliance management requires establishing and maintaining a transparent information system and a response system. The information system must produce adequate and accurate information about actors' behaviours under the treaty. The managerial response system must then produce discriminating responses to different types of non compliance, using both multilateral, treaty based and unilateral actions to induce change". ${ }^{28}$
}

In Intentional Oil Pollution at Sea, Mitchell distinguishes three types of compliance systems and they are: the primary rule system; the compliance information system, and the non-compliance response system. This falls within the Chayes and Chayes concept, with the added factor of being concerned also with the primary rules of the treaty. For the purposes of this article the Mitchell framework will be used when a treaty management/compliance system is examined.

The primary rule system sets the basic parameters of the treaty. It determines the players who will be involved, the changes in behaviour required of them, and the new regulations by which they will have to abide. The compliance information system identifies the players involved in reporting on parties' compliance or lack

28 A. Chayes, A.H. Chayes and R. Mitchell, "Managing compliance: a comparative perspective", in Brown Weiss and Jacobson, n. 11, at 42. 
of it, as well as the mechanisms to be used in gathering and disseminating that information. The non-compliance response system determines the type and degree of action that should be taken in the event that non-compliance should occur.

These three work together. Primary rules establish the new boundaries; the information system sees whether those boundaries are being adhered to, and the response system is to act if the information points towards non-compliance. It takes no leap of faith to see that the clearer and better are defined the primary rules, the more stringent is the information gathering, and the more efficient is the response system, then the better the compliance should be. In the absence of any external factors influencing or enforcing compliance, the workings of a treaty's compliance system should be examined by a researcher in order to determine precisely those factors within the treaty provisions that induce the parties to behave appropriately.

\subsubsection{Primary rule system}

The primary rules laid down by a treaty are highly influential on compliance. They determine the standards that have to be set, as well as the new behaviour patterns that have to be followed. This would mean the determination of costs and new activities. The way such rules are structured and the burden they place on parties will have an influence on compliance, thus if there is a greater burden on developed States, this may mean greater compliance because these States have the resources and perhaps the internal pressures (as incentive) to do what they have agreed to do.

If the primary rules encourage transparency in the treaty processes, so much the better: if it is easy to see when there is non-compliance, this should have a two-fold effect. Firstly, transparency would encourage compliance because of the parties' fear of discovery of non-compliance and, secondly, because transparency would ensure that those who do comply do so for all to see. These aspects make it easier to deal with the 'bad' and reward the 'good'. It is important, therefore, to make sure that the acts to be regulated are those that are the most straightforward to monitor.

Specificity is a factor to encourage compliance. The clearer are the rules, the more certain the parties will be as to where they stand. This, again, will make it easier for those who wish to comply and harder for those who may try to avoid compliance through so-called 'misunderstandings' and 'misinterpretations'. Of course, establishing very specific rules throughout the treaty may be difficult because of the nature of treaty making; ${ }^{29}$ however, it is an ideal towards which the treaty should aim, so that even if not all of the provisions are specifically worded, a good proportion is clearly defined.

At this point, it is submitted that taking Mitchell's logic to its conclusion, surely if higher levels of compliance are required, the optimum type of primary rules would be those that are most clearly worded and easiest to follow. There lies in this approach the danger that rules may be designed to elicit compliance for compliance's sake:

29 If States feel a treaty provision may be too burdensome to them, then it is possible that they will either not agree or make moves for reservations. 
it would render the treaty a working and respected law, yet would do nothing for the problem it seeks to rectify.

\subsubsection{Compliance information system}

The intention of a compliance information system can be summed up in one word: 'transparency'; it is:

"[T]he adequacy, accuracy, availability, and accessibility of knowledge and information about the policies and activities of parties to the treaty, and of the central organisations established by it on matters relevant to compliance and effectiveness, and about the operations of the norms, rules and procedures established by the treaty". ${ }^{30}$

A sound compliance information system has therefore to collect a wide range of relevant, accurate, reliable, and legitimate information on compliance and effectiveness, which is also made available to the public.

Transparency is vital to the good management of treaty compliance because it plays several important functions. Without good transparency it would be difficult to co-ordinate actions. It is also a reassurance for Member States to learn of the levels of compliance of the other Members to a treaty. It is necessary for States to feel secure in the fact that the other States are making efforts to accomplish that which is required of them. 'Free riding' would also be harder to achieve if transparent checks were able to show that some States were simply not fulfilling their obligations. Such openness has the further advantage of being a deterrent to States to fail to comply. ${ }^{31}$

The major issue here is that it is often difficult to obtain information: not necessarily from the point of view of recalcitrance, but from an inability to do so well. ${ }^{32}$ It is important that the treaty take into account certain points when demanding data. Obtaining data from large groups is harder to achieve than from small groups; therefore, if the same data can be obtained from a source with fewer actors, gathering data would be made much easier. ${ }^{33}$ Furthermore, the type of information required has to be within the technological capability of the States involved. ${ }^{34}$

${ }^{30}$ Chayes, Chayes and Mitchell, n. 28, at 43.

${ }^{31}$ Charney, "Non-legal sanctions in commercial relationships" 104 Harvard Law Review 373-467, and Koehane, Hegemony: Co-operation and Discord in the Political World Economy, Princeton: Princeton University Press, 1984, suggest that negative reputation impacts and diffuse reciprocity may be adequate in deterring non-compliance.

32 An International Labour Organisation Working Group as reported in Chayes, Chayes and Mitchell, n. 28 , at 46.

33 Vogel and Kessler, n. 24, at 24-25.

${ }^{34}$ In his book, Intentional Oil Pollution at Sea, Mitchell notes how monitoring of the dumping of oil from ships became easier when the monitoring shifted from actual polluting acts to ensuring that each ship is equipped with the required pollution control devices. It was technically very hard to trace discarded oil to the culprit, whereas it is easier to check that ships are properly equipped. 
This still leaves the issue of the actual data gathering. Self-reporting is the easiest method applied by a treaty for demanding data, but it really needs to be supplemented by other means. The Convention on International Trade in Endangered Species of Wild Fauna and Flora 1973 (CITES), for example, has a double reporting system: one report comes from the exporting State and one from the importing State. This serves to act as a self-checking mechanism. It is submitted that what is required is to open the entire process to include as many bodies as possible in the task, rather than limiting data collection to the States themselves. In practical terms, this would entail the involvement of Non-Governmental Organisations (NGOs).

The expertise of NGOs should be exploited to the full when gathering data. Bodies such as Traffic and Wetlands International are vital cogs in the smooth working of CITES and RAMSAR. ${ }^{35}$ However, NGOs are more important than as mere data-gatherers. If transparency is to be taken seriously, the concept should include the entire international environmental law system.

Cameron $^{36}$ argues for greater openness in the international legal process. This would include treaty processes, i.e., the phases from the forming of the treaty through to its actual application. Basing the process on a constitutional law model, he argues in favour of the importance of transparency and public (in Cameron's case, the emphasis is on NGO) participation.

The participation of non-governmental bodies has been acknowledged by the United Nations in its Charter, particularly Article 71, which states:

"The Economic and Social Council may make suitable arrangements for consultation with non-governmental organisations which are concerned with matters within its competence. Such arrangements may be made with international organisations and where appropriate, with national organisations after consultation with the Member of the United Nations concerned".

The UN has in many conferences and treaty-making exercises used this facility. The watershed for NGO participation came with UNCED where the precedence was set to accommodate NGOs by simplifying accreditation rules, ${ }^{37}$ as well as by giving NGOs opportunities to make their views available to participants through the publishing of statements in all of the official UN languages. This broadening of participation has been carried on into post-UNCED events such as HABITAT II in Istanbul 1996. In the context of designing a transparent treaty system, this sort of encouragement towards non-governmental bodies should be embraced. Apart from the monitoring role and the information-gathering/dissemination role, NGOs may often have at their disposal expertise useful to governments with a limited capacity.

\footnotetext{
${ }^{35}$ RAMSAR Convention on Wetlands of International Importance, Especially as Waterfowl Habitat, 1982.

36 "Compliance, citizens and NGOs" in Cameron, Werksman and Roderick, n. 7.

${ }^{37}$ UNCED Rules of Procedure, Rule 65 Decisions 1/1: Role of NGO[s] in the Preparatory Process for UNCED.
} 
To summarize, a compliance information system is intimately linked to transparency. Monitoring by self-reporting and the empowerment of NGOs are vital to this aim. On-site monitoring is another method of improving a compliance information system. The treaty provisions should be designed so as to enhance the flow of information between and among parties. The provisions should also increase the resources that would allow for maximum monitoring. The more effective a treaty is to be in this sense, the greater the number of groups and individuals that should be given the ability to participate in the monitoring and information system. The wider the range of actors who can process, disseminate and analyze data, the better, as sources of compliance and non-compliance can be identified - and rewarded or punished, as the case may be.

\subsubsection{Non-compliance response system}

The treaty should also include provisions that facilitate compliance and sanctions non-compliance. Sanctioning violations need not mean the treaty's providing for aggressive acts. The provision of a regular conference of parties could have an important effect. It allows all States to be recognized, 'good' or compliant States to be acknowledged and 'bad' or non-compliant States publicly to be exposed and shamed. Information could be shared and new developments discussed.

It is possible that disputes may have arisen over the respective duties of States. Dispute resolution helps to clarify norms and to remind parties of their duties. It is also desirable that a treaty provide specific enforcement measures in the event of non-compliance. It is also possible, as with the United Nations Convention on the Law of the Sea, to have a compulsory dispute settlement mechanism. ${ }^{38}$ Non-contentious methods of dispute settlement are to be aimed at. ${ }^{39}$

A treaty should also make it hard for violations to occur. For example, with pollution control, instead of trying to apply a limit on effluent, a treaty should instead make it compulsory for pollution control devices to be installed. In this way pollution does not become an option..$^{40}$ Most disputes are settled by negotiation. But what if negotiations fail? Binding arbitration/litigation has had a relatively small role in solving environmental law disputes. The processes are costly, contentious, cumbersome, and slow. Furthermore, far more work needs to be done if smaller, less-developed countries are to be able to face richer partners in court on equal terms (it may be argued that negotiation faces the same problem and is possibly less helpful because there are few rules of engagement - nor is there a judge to ensure fair play). Negotiations also raise the political visibility of the problem yet are often not subject to the control of the parties involved.

The method of dispute settlement matters less than the fact that the parties accept the outcome as authoritative. The Convention on International Civil Aviation 1944 has a Council that deals on a rather informal basis with questions of interpretation;

38 Annex VII of the Convention.

39 Chayes, Chayes and Mitchell, n. 28, at 54-56.

40 See n. 34. 
it favours settlement by political and diplomatic means, rather than through confrontational arbitration. The trend now is towards binding arbitration, as used by the WTO after the Uruguay Round. A middle ground is comprised of compulsory conciliation culminating in a non-binding recommendation from the conciliators if the parties fail themselves to come to an agreement. Even though the conciliators' decision is not binding, it is still influential and is likely to carry weight with those parties in dispute as well as all parties in general.

Another method is the authoritative or semi-authoritative interpretation by a designated body of the international organization, for example, the Secretariat. This provides a less contentious method of treaty interpretation. Furthermore, it can also prevent parties from failing to comply by arresting the States from committing themselves to activities that clash with the goals of the regime. The non-formal and non-confrontational nature of such a system also means that it is highly probable that States will submit questions of interpretation. An on-going process such as this would go some way towards rendering the treaty a vital and "live" one. Furthermore, it is unlikely that States would reject the answers to questions that they themselves had submitted.

\subsubsection{Other actions to encourage compliance}

With regard to facilitating compliance: the main concern should be capacity building for Member States who may, without help, otherwise not be able to comply. This includes financial, technological ${ }^{41}$ and educational help. Apart from the direct benefits such help may provide, party States may be encouraged to report if they believed that they would obtain assistance as a result of the said reporting. For example, a State may be less reluctant to report its failures if it knew that such reporting could lead to some form of help and thus benefit for itself.

The problem here, of course, is to find sources of financing for such capacitybuilding exercises. Treaties now ought to have a mechanism that allows for wealthier nations to help poorer ones. The Montreal Protocol Multilateral Fund, the Climate Fund of the Framework Convention on Climate Change, and the Global Environmental Facility proceed on the premiss that developing countries need financial and technical assistance. All of these mechanisms are designed not just for operating projects, but for education and training, the improvement of scientific capacity, assistance to planning departments, the enhancement of data systems, and the like.

The treaty should be open to change and adaptation in order for it to remain vital. Traditional change would mean a slow process involving amendments. The possible adverse effects of delay can be overcome in several ways. Framework treaties provide skeleton of a law which can then be fleshed out in future documents, and constitute one such way. This has been successful with the 1985 Vienna Convention for the Protection of the Ozone Layer and its more substantial sister treaty, the 1987 Montreal

41 Care has to be taken to ensure that aid such as technology transfer is not only compatible with the nations receiving it, but is also up to date: technology transfer would be reduced to a farce if developed States used it as an opportunity to 'dump' defunct technology on needy countries. 
Protocol. However, in contrast, the 1992 Climate Change Convention has experienced great difficulty in seeing any significant flesh added onto its skeletal frame.

Other methods include for the treaty to provide a body that can 'interpret' the Articles of the treaty, as is done by the IMF Agreement. Special provisions for changing the "technical" regulations, allowing for a simpler method for changing "technical" aspects of the treaty, is a helpful way of making changes relatively quickly: a majority vote, for example, to a change that affects the annex of a treaty, as in CITES.

Changes in the treaty depend on the parties' view of the success of the treaty. If compliance is good then it may wish further to improve the standard; $f$ compliance is poor, then an investigation is required into why this is so. There is no point in amending the treaty to become more specific when the problem is a financial one. What must be noted is that change is necessary for the ultimate survival and relevance of a treaty.

Brown Weiss and Jacobson ${ }^{42}$ contend that the following measures should be taken to improve compliance in the short term. Creating communities of interested parties, especially scientists and specialists in the topic, or what has been termed "epistemic communities". More scientists lead to more information, greater understanding and therefore better compliance. Involving domestic officials and bureaucracies, so that their personal interests and reputations become issues at stake, also increases the motivation to comply. Encouraging greater personal involvement and wider networking with international peers mean that individual government servants are more likely to do their best.

To conclude this part of the article, there is a sense that looking towards an authoritarian figure or some form of harsh treatment of offenders is not the preferred approach of eliciting compliance. The writer concurs with this. It would seem that the way forward is to be found in the serious democratization of the international law processes. This means the use of human rights, both substantive and procedural, to empower citizens in the taking of legal and political action themselves without their having to depend on States to do so. It means also the opening up of the treaty processes, allowing as many actors into these as possible, to encourage transparency and a constitutional model of international law.

Treaty design may have an important task to play, too. If the Chayes and Chayes and Mitchell theory is correct, the shape and form of the treaty should play a major role in State compliance. This theory will now be applied to the Malaysian scenario. It is hoped that this will shed more light on the topic by seeing how and why a developing nation complies and how viable are the theories discussed above when applied to the context of the said country. The treaties chosen for further study are the Washington Convention on International Trade in Wild Flora and Fauna 1973 (CITES) ${ }^{43}$ the Basel Convention on the Control of Transboundary Movement of Hazardous Wastes and their Disposal 1989 (Basel) ${ }^{44}$ and the Ramsar Convention

42 Brown Weiss and Jacobson, n. 11, at 10.

4312 ILM 1088 (1973).

4428 ILM 657 (1989). 
on Wetlands of International Importance Especially as Waterfowl Habitat 1971 (Ramsar). ${ }^{45}$ These Treaties are all established instruments; thus, it would be easier and fairer to examine the Malaysian government's performance of them, because sufficient time has passed for consideration prior to ratification and for necessary post-ratification action to have been taken. ${ }^{46}$

These Treaties are also sufficiently specific in nature and the responsibilities placed on the parties reflect this. ${ }^{47}$ They are also (as their full titles suggest) quite diverse. It is therefore hoped that such diversity will imbue the paper with a broad enough spectrum to provide a satisfactory overview of compliance - and the application of compliance theory - with international environmental law in Malaysia.

\section{COMPLIANCE WITH CITES IN MALAYSIA}

As its full title suggests CITES is about the control of international trade in rare species of plants and animals. It is not limited to live specimens, but also concerns dead specimens or parts of specimens (Article I). The main method through which trade is controlled is by a system of appendices and permits. If a species is placed on any one of the three appendices provided for by the treaty, then trade in this species is controlled. Appendix I is reserved for endangered species and trade for commercial reasons ${ }^{48}$ may not take place (Article III). Appendix II is for species that are not yet endangered, but which could become so if trade is not controlled (Article IV). This being the case, then some method of regulation is required to keep international trade in these species limited. Appendix III is basically a list of species that individual parties can insert without the need of approval from the other members (Article V). In other words, if Country A wishes to protect one of its domestic species yet is uncertain whether it can obtain the necessary support of other members to vote that species into either Appendix I or II, then it can unilaterally place it into Appendix III, thus providing it with some form of trade protection which the other parties are

\footnotetext{
4511 ILM 969 (1972).

46 Malaysia ratified these treaties in 1977, 1994 and 1993 respectively.

${ }^{47}$ Furthermore, it is submitted that the other treaties to which Malaysia is do not raise sufficient compliance issues. The Convention Concerning the Protection of the World Cultural Heritage does not demand very much action on the part of its parties. The same applies to the Vienna Convention for the protection of the Ozone Layer (along with its protocols) and the United Nations Framework Convention on Climate Change. These last two treaties require no action from countries that are still developing; Malaysia falls into that category. The Convention on Biological Diversity is a vague framework treaty that also places no serious obligations, and the Convention to Combat Desertification is quite easy to comply with in a country with a tropical climate.

${ }^{48}$ Resolution 5.10 of the Conference of Parties: Definition of Primary Commercial Purposes, states that commercial purpose would mean an activity whose purpose is to obtain economic benefit, including profit. "Commercial purpose" is also more about the use of the specimen once it has been obtained. It is possible that a commercial transaction may take place in the acquisition of the specimen, but this need not mean that once acquired, the specimen will be used for commercial purposes.
} 
not only obliged to respect but are also obliged to take practical measures to ensure that trade in the said species is controlled.

In order to obtain a permit to export a specimen listed in Appendix I, the approval of the Management Authority (MA) and the Scientific Authority (SA) must first be obtained. The MA will determine that the specimen was not obtained illegally, that the transport of any live specimen is safe and will not harm it, and that its export is not for commercial purposes. The SA will give its approval only if the export of the specimen is not detrimental to the survival of the species. For Appendix I species, there is also a need for an import permit to be obtained. The import permit is granted by the SA and MA of the importing country; its criteria are similar to those of the exporting State. In other words, there is a system of double-checking to ensure that the export is totally above board.

For Appendix II specimens, the criteria are similar, but there is no need to ensure that the export is carried out for non-commercial purposes: Appendix II specimens may be traded. There is also no need for an import permit. The primary obligation of parties is to ensure a working MA and SA along with the necessary legislation so that the permit system can be implemented. Another important obligation is the duty to publish annual reports with which the Secretariat and the Conference of Parties can monitor the activities of individual States.

Malaysia has by and large been able to put in place the necessary laws and institutions for it to comply with CITES. ${ }^{49}$ The main pieces of legislation making it illegal to procure specimens without prior consent are the Protection of Wildlife Act 1972 (PWA) ${ }^{50}$ and the Fisheries Act 1985 (FA). ${ }^{51}$ The PWA has lists of animals and birds, classifying them as "protected" and "totally protected". It is an offence to take, harm or even be in possession of these species without the approval of the government in the form of licenses for "protected" species and of ministerial approval for "totally protected" species. With regard to fish, the Fisheries (Control of Endangered Species of Fish) Regulations 1999, ${ }^{52}$ made by virtue of the FA, lists several species of aquatic life that cannot be taken, harassed, possessed or harmed without permission from the Department of Fisheries. Naturally, considering it is a treaty about trade, customs officials and customs legislation form a vital part of the implementation of CITES. In Malaysia the Customs Act $1967^{53}$ governs this aspect of law enforcement. The Act provides that restricted goods may not be

\footnotetext{
49 The Malaysian legal system is quite unique in that the states of Sarawak and Sabah have constitutionally provided extra legislative powers. Therefore, with regard to wild flora and fauna, they have their own separate legislation and implementing bodies, whereas in Peninsular Malaysia these matters are in the purview of the Federal Government. To avoid confusion, however, this article will focus primarily on the laws and institutions of Peninsular Malaysia. Reference to Sarawak and Sabah will, of course, be made when relevant. It is submitted, though, that by and large the issues faced by the authorities on Peninsular Malaysia are similar to those faced by their Borneo cousins.

${ }^{50}$ Laws of Malaysia, Act 76.

51 Laws of Malaysia, Act 317.

52 P.U.(A) 409/99.

53 Laws of Malaysia, Act 235 (Revised 1980).
} 
exported from or imported into the country (Section 31). By virtue of Section 31, CITES specimens will thus need the requisite permits in order to be allowed through customs. Within the PWA and the FA provisions are made to punish those who commit offences under them.

Regarding the CITES institutions, the Management Authority in Peninsular Malaysia is the Department of Wildlife and National Parks (PERHILITAN), which is a Federal department under Ministry of Science, Technology and the Environment (MOSTE). Although PERHILITAN is the Management Authority, it does not bear the entire burden of this responsibility by itself. PERHILITAN as a body is expert primarily in land-based animals. Therefore, when it comes to flora and marine life, it requires the help of the Department of Agriculture (DOA) and the Department of Fisheries (DOF) respectively. These two bodies aid PERHILITAN in the granting of permits. The DOF grants the permits for all fish specimens, while the DOA grants the permits for all flora specimens.

The Scientific Authority is officially the Ministry of Science, Technology and the Environment (MOSTE). Specifically, the Environmental Protection and Management Division of MOSTE holds this responsibility. The most important point to be made here is that MOSTE is by no means a scientific organization. It is a government bureaucracy and as such lacks the necessary expertise to do what is required of it by CITES. This problem is circumnavigated by the CITES Committee, consisting of several bodies, each with its own expertise. Theoretically, what the committee should have is enough knowledge collectively to perform the function of a CITES Scientific Authority. The members of the committee include the Department of Agriculture, the Department of Wildlife and National Parks, the Fisheries Department, the Ministry of Primary Industry, the Ministry of Foreign Affairs, the Department of Customs and Excise, and the Malaysian Forest Research Institute.

What is particularly striking about this mix of bodies is that although some of them seem clearly relevant others do not; they may in fact even appear slightly sinister. Looking at the job of the Scientific Authority, its primary concern is to ensure that if a particular specimen is exported, this action will not create a danger to the species as a whole. One can see where the Fisheries Department or the Department of Agriculture might have the ability to determine this fact. However, where does the Ministry of Foreign Affairs fit into this? Worse still, the Ministry of Primary Industry's ambit is the exploitation of natural resources such as timber, so what role does it play as part of the "Scientific Authority"?

This leads to the issue of compliance. On the surface it does appear that the necessary actions have been taken by the Malaysian government to implement CITES. The permit system is active and is very much part of the established bureaucracy. The problem with CITES in Malaysia is not one of non-compliance, but instead it is really one of poor compliance. The reasons for this are examined below. 


\subsection{Problems with Malaysian CITES Compliance}

The weaknesses in Malaysian compliance with CITES can be summarized as a lack of expertise, poor legislation, a lack of resources, and poor environmental awareness. These points are discussed in detail below. Much of the information is obtained through interviews with officials in the various governmental bodies entrusted with the implementation of CITES.

\subsubsection{Lack of expertise}

The most prominent problem with the implementation of CITES in Malaysia is, arguably, the lack of expertise. This is not to say that there are no capable individuals working on CITES obligations. When discussing the matter of expertise, there are two strands to the issue. Firstly, it has to be said that there exist bodies that are simply incapable of carrying out the job which they are supposed to be doing, be it through a lack of training or simply through being the wrong sort of entity in the first place. Secondly, although expertise does exist, it exists in different forms and in different places. There is, therefore, the issue of bringing these disparate bands of expertise together in a coherent fashion so as to enable better CITES compliance.

As pointed out earlier, the Scientific Authority is more of an administrative body and not a scientific one as such. Decisions made by the CITES committee tend to be of a broad policy nature. ${ }^{54}$ The CITES committee is more concerned with the listing exercises of CITES: that is, to say when a new species is to be added into any of the appendices. Decisions made on these exercises appear to be political and economic rather than environmental in nature. Domestic interests take precedence, thus when it was proposed that Merbau and Ramin wood be included in the Appendices, this was soundly opposed by the MOSTE, prompted largely by the Ministry of Primary Industries (which would explain the presence of its representatives in the committee). Other considerations taken into account by the committee includes the maintenance of cordial ties with fellow developing countries, particularly the G77. Therefore, Malaysia objected to the inclusion of Mahogany into Appendix I even though it is not an indigenous plant and has no economic relevance to the country. Mahogany is, however, economically important for Brazil - a G77 country and an ally who has to be supported.

One objectionable factor regarding the CITES committee is not that it is making decisions based on political or economic expediency which, to a certain extent, is to be expected of any government; the issue here is the lack of a proper Scientific Authority capable of doing the main duty the treaty has set out for it to do. That is to say, the body should ensure that any export or import will not be detrimental to the survival of the species as a whole (Article III (3)(a), IV (2)(a) and IV (6)(a) of CITES).

54 Interview with MOSTE, 14 July 1997. 
In Malaysia, for all practical purposes, the Scientific Authority is PERHILITAN, the same body that is the Management Authority. This is also not a completely satisfactory circumstance. Although it is much better to have a body with some scientific expertise doing the job of the Scientific Authority, it should be pointed out that PERHILITAN's expertise is limited to wild animals and birds, and the situation is far from ideal. Even within their own area of expertise, there are problems: there is no baseline information regarding the species available for trade; the approximate numbers that are available is limited to large mammals. ${ }^{55}$ Yet these animals are not the ones being traded, given that they appear in Appendix I. Without this baseline information, there is no real scientific basis to make the decision as to whether it is safe for the species as a whole to allow trade to continue. The situation is even worse regarding fish and fauna: the relevant bodies with the expertise, the Fisheries Department and the Department of Agriculture, are not agencies with protection as their primary concern; their greater concerns lie with the fishing and agricultural industries and not with the protection of fish and fauna. Furthermore, having one body doing the work of both the Management and the Scientific Authority diminishes the double protection of having two separate bodies determining the wisdom of allowing a particular specimen an import or export permit.

The problem of a lack of expertise manifests itself in the way that CITES works in Malaysia. From the earlier descriptions, it can be seen that the system depends on a variety of bodies all working together. For example, PERHILITAN may turn to the DOA when faced with a decision regarding a plant specimen; and a case of marine life will have to be referred to the DOF. This is not a criticism per se, for many countries, particularly smaller developing countries, simply do not have the resources to establish one central body to work specifically on CITES. However, the problem that arises is one of co-ordination. ${ }^{56}$ With so many bodies each working on a small part of the greater whole, there is a need for strong central body and an efficient co-ordinating mechanism to ensure that decisions are made quickly, accurately and efficiently. Unfortunately, neither of these elements exists in the Malaysian context. The Environmental Protection and Management Division of MOSTE consists of the head, one officer and a handful of clerical staff. This small number of staff, along with their other non-CITES related duties mean that they simply do not have the resources to play the role of a pro-active CITES co-ordinator.

The system which exists regarding co-operation is also very ad hoc in nature. Although interviews with officials from PERHILITAN, DOF, DOA and Customs and Excise did not disclose any dissatisfaction with the system, the fact remains that the lack of a formal framework is a serious shortcoming. The ad hoc way in which the day-to-day running of CITES currently occurs may suit government officers for the moment, as a comfortable pattern of practice would normally emerge. However, any changes or improvements to the system become difficult to implement without proper organization.

55 Interview with PERHILITAN, 28 November 2001.

56 Interview with Chen Hin Keong, Director of TRAFFIC Southeast Asia, 25 July 1997. 
An example would be new training. In July 1996, the CITES Secretariat with the co-operation of MOSTE held a training seminar in Malaysia. There were 60 participants, mainly from various relevant government departments. The seminar was about the implementation of CITES and it was in general well received. Most of the officers interviewed had attended this seminar and found it of help. An interesting point is the question of the dissemination of knowledge. In an interview with an official from Customs and Excise, it was asked how the new knowledge that had been gained from the seminar would be disseminated across the Department. ${ }^{57}$ The method used is for the officer who had attended the training seminar to write a report; this would then be submitted to a superior who would then decide whether the recommendations in the report should be acted upon or not. It is true that this system of hierarchical decision-making is usual and should be expected; the point is rather, that with regard to CITES, without a strong co-ordinating central body responsible for CITES as a whole with a rebit for action, all that is left are the perseverance and interest of individual officers, if any changes are to be made. A CITES co-ordinating body could provide the extra authority and systematic methods through which changes can occur.

Another problem with an ad hoc system of operations is that it makes data gathering a haphazard exercise. Without a proper data-gathering mechanism under the administration of a single responsible body, the results could be less than satisfactory, especially now since the Fisheries Department and the Department of Agriculture are to process permits themselves. As it stands, data gathering is erratic and not entirely satisfactory.

\subsubsection{Weakness in legislation}

The most serious shortcoming in Malaysian wildlife legislation is the complete lack of any specific law for flora. The legislative protection that exists for the protection of plant life is secondary in nature. For example, the National Forestry Act $1984^{58}$ has provisions preventing the taking of plants without a permit, but this depends on the prior protection of a specific area of land. Thus, if a forest reserve is set aside, then the plants on that land cannot be taken. This is not good enough, as plants are subject to a great deal of over-exploitation and unsustainable harvesting. An example would be the slipper orchid (Paphiopedilum) and cycads taken from the wild and openly sold in nurseries. ${ }^{59}$ There are insufficient laws properly to stop this practice; even if a provision of the the National Forestry Act were broken, officers are more concerned with timber products than with decorative plants (such as cycads) to take much action over the unlawful taking of flowers. Furthermore, there is no legislative power to take action against individuals who have transported flora. ${ }^{60}$ This is naturally a serious setback with regard to CITES enforcement and compliance.

57 Interview with Royal Malaysian Customs and Excise, 22 July 1997.

58 Laws of Malaysia, Act 313.

59 Interview with Forest Research Institute Malaysia, 24 July 1997.

60 Interview with Plant and Plant Quarantine Division, Department of Agriculture, 24 July 1997. 
A rather strange legal anomaly is the Fisheries (Control of Endangered Species of Fish) Regulations 1999. This regulation lists species of whales, dolphins, manatees and clams (which are mammals and shellfish), but the only fish species in the list is one species of whale shark. Considering that the CITES species that are found in Malaysia include some rare and endangered fish, this does seem to be a serious shortcoming. Furthermore, the Fisheries Act deals only with marine fish; river fish, many of which are endangered, do not by virtue of the Malaysian constitution's division of legislative powers fall under the jurisdiction of the Fisheries Act and instead are within the purview of regional governments. These fail to provide any sort of protectionist legislation.

Another issue concerns the low penalties imposed on lawbreakers. This has two effects. Firstly, the penalties do not act as a sufficient deterrent to those involved in such illegal activity, and secondly, they give the impression that such crimes are not very serious. Furthermore, the low penalties may have an adverse effect on the attitude of law officers towards such crimes. For example, one PERHILITAN officer complained that the courts tend to be too lenient on offenders. It is not within the ambit of this research to examine the cause and effect of low penalties as deterrence. However, an examination of the records shows that low penalties constitute an issue that needs to be addressed:

1996: 4528 fines with a total of RM 231,095 collected (an average fine of RM 51)

1997: 4079 fines with a total of RM 218,275 collected (an average fine of RM 53)

1998: 4378 fines with a total of RM 316,170 collected (an average fine of RM 72)

1999: 3578 fines with a total of RM 190,515 collected (an average fine of RM 53)

The following figures are those of the total fines collected from compound offences as well as those from court decisions. The number of court cases is itself very small:

1996: 39 fines with a total of RM 8,970 collected (an average fine of RM 230) 1997: 42 fines with a total of RM 32,350 collected (an average fine of RM 770) 1998: 21 fines with a total of RM 62,750 collected (an average fine of RM 2988) 1999: 14 fines with a total of RM 43,590 collected (an average fine of RM 3113)

From these figures it can be seen that once a case goes to court, the sentences meted out are significantly higher than the total average. However, it can be argued that the severity of the cases should warrant sterner punishment due to the endangered nature of the species involved. Furthermore, the vast majority of cases are compound offences, even for protected and totally protected species. In compound cases, the average fine is very low. For example, compound cases involving protected species in 1999 totalled 1403. The fines collected amounted to RM 171,931. The average fine was RM $123 .^{61}$

${ }^{61}$ Figures obtained from the Wildlife Department Annual Report 1996, 1997, 1998 and 1999. 


\subsubsection{Lack of resources}

This is a problem endemic in many areas of Malaysian environmental protection. Looking at the CITES-related bodies, one can see that a shortage in manpower is chronic. As pointed out above, the Environmental Protection and Management Division of MOSTE, the main co-ordinating body for CITES enforcement, consists of two officers and a handful of clerical staff. The shortage of finance and trained personnel also means that there are insufficient people to fulfil basic requirements such as data gathering, monitoring and reporting. For example, there has been no study conducted on any illegal trade in Malaysia; therefore, there are no available figures at all. There are suspicions that Malaysia is a transit point for illegal trading, but again, there is no concrete evidence as no study has confirmed or refuted this.

Whatever evidence exists comes from the occasional cases where an illegal shipment of specimens is found. In February 2000 smugglers were caught with 901 snakes, brought into Malaysia from Thailand en route to Singapore and thence to China, Taiwan and Hong Kong. In the same month, 1000 snakes were seized at a roadblock. It is believed the snakes are from Thailand, bound for Penang, where they will be processed before being exported. ${ }^{62}$

Perhaps more important is the lack of data on the numbers of each species of animals and plants in the country. Without such hard data it is difficult to make decisions regarding the viability of their trade. Species that are clearly endangered are protected because they will be in Appendix I; therefore, no trade is allowed at all. However, species that are still relatively abundant can still be traded under Appendix II. The number that may be exported has to be determined by the Scientific Authority, yet in order to do this effectively and with the safety of the survival of the species in mind, there has to be some baseline information regarding the numbers of the species as a whole.

\subsubsection{Lack of environmental awareness}

Proper training is vital in the enforcement of CITES; the lack of training is most notable in the Customs and Excise Department. Customs officers are simply not sufficiently well trained in recognizing specimens. Their role in CITES appears to be limited to the checking of permits. This is clearly not enough. Admittedly, when in doubt, customs officers refer to bodies with the necessary expertise, such as the Wildlife Department or the Department of Agriculture. However, interviews with both these bodies show that although such steps may be effective when situations of doubt occur, there is on the whole still a major problem, namely, that of identification of what is on the permit and what is actually before the officer's eyes. It is possible that the two do not match; with insufficient training, the discrepancies will not be spotted. This is especially important in cases of specimens in transit because

${ }^{62}$ TRAFFIC Bulletin, Vol. 18, No. 2 (2000). 
these then lie completely within the control of the customs officers (Article VII (1) of CITES).

In a way, this is not surprising, as environmental matters do not constitute the priority of the Malaysia customs service. The emphasis is on the monitoring of imports which are a threat to culture and religion, and on the collecting of revenue from duty. Exports are not closely monitored since they bring in revenue into the country and are thus encouraged. Customs officers also receive very minimal training on environmental matters. The official course for customs officers at the Royal Malaysian Customs Academy in Melaka has no courses designed for environmental awareness, with the exception of timber identification. ${ }^{63}$ Training related to CITES is irregular and limited to the occasional attachment to other government departments or to specific short courses like the 1996 CITES seminar. Even then, the seminar was not geared towards customs officials.

The lack of awareness is, of course, not limited to customs officers. There is a lack of environmental awareness in the entire legal system from the Attorney General's Chambers to judges. ${ }^{64}$ This raises the point that the laws are only as effective as those who enforce them. Some type of training in the form of consciousness raising is required - especially in an area where the damage done by the lawbreakers is not patently obvious to everyone.

\section{COMPLIANCE WITH BASEL IN MALAYSIA}

The Basel treaty is primarily concerned with the exportation of hazardous wastes to countries that do not have the capacity to treat it safely. It is the result of many shocking practices, primarily in the early nineteen-eighties when developed nations were dumping their waste in developing nations because this was cheaper than treating it at home. Poor nations desperate for money would accept these wastes as an easy way of boosting their finances, resulting in environmental damage and unacceptable risks to life. ${ }^{65}$

\footnotetext{
${ }^{63}$ The Malaysian Royal Customs Academy's Training Programme Syllabus 2000 has no environmental component.

${ }^{64}$ The Attorney General's Chambers, as well as the Judicial Service, confirmed that there is no environmental awareness training given to their personnel. The author asked these bodies on 20 November 2001 and 15 November 2001 respectively.

${ }^{65}$ See Toxic Terror: Dumping of Hazardous Wastes in the Third World, Third World Network, Penang, 1988, D.P. Hackett, "An assessment of the Basel Convention on the Control of Transboundary Movements of Hazardous Waste and Their Disposal", 5 American U.J.Int'l Law \& Policy 291 and D.J. Abrams, "Regulating international hazardous waste trade", 28 Columbia Journal of Transnational Law 801 (1990).
} 
The main principles of Basel can be summarized as follows: ${ }^{66}$

a. All generation of hazardous wastes should be kept to a minimum;

b. If this cannot be done, disposal should preferably be done as close as possible to the source;

c. In the following cases, waste cannot be exported at all: to Antarctica, to nonparties of Basel (unless there is a separate bilateral treaty), or to parties which have banned the import of hazardous wastes;

d. Transboundary movement of hazardous waste is a 'last resort' measure that can take place only if the movement complies with the rules and regulations established by the treaty, if it is the best option from an environmental perspective, and if it is done under the principle of non-discrimination and according to the principle of environmentally sound management;

e. The foundation of the Basel regime is the system of Prior Informed Consent (PIC) of the potential importing State and all transit States, and

f. Hazardous waste exported illegally and that which cannot be treated safely in the country of destination is to be shipped back to the source.

In order to implement Basel, a party State would have to put into place a mechanism that would enable the PIC system to work. According to the treaty, this would mean the establishment of a competent authority and a focal point (Article 5). These bodies will be responsible for the dissemination of information regarding the movement of wastes from their country and also for approving (or rejecting) the importation and transit of wastes.

According to Article 4(9) of the treaty, hazardous waste can be exported only for the following reasons:

a. The exporting State does not have the capacity to dispose of it in an environmentally sound manner;

b. The waste in question is required for as a raw material for recycling or recovery industries in the importing state, and

c. The Transboundary movement falls into any criteria determined by the parties, as long as it does not contradict the objectives of the treaty.

Any traffic that falls under one of the following descriptions is illegal traffic and Parties must ensure that they have the necessary laws to punish the wrong doers (Article 4(3)):

a. Without notification as set out by the treaty to all parties concerned;

b. Without the consent of a state concerned;

c. With consent obtained through fraudulent means;

d. That does not match up to the documents, or

${ }^{66}$ K. Kummer, International Management of Hazardous Wastes: The Basel Convention and Related Legal Rules, New York: Oxford University Press, 1995, at 47. 
e. That results in disposal which is in contravention with the treaty or any other international law.

On the domestic front States are required generally to ensure, as far as their local conditions (economic, social and technological capacities) allow, minimizing the production of wastes. They are also to provide for adequate disposal facilities within their own borders and to control the persons involved in the management of hazardous wastes from causing pollution. The export of hazardous waste ought to be kept to a minimum (Article 4(2)(a)(b)(c)(d)).

Malaysia has an entire system of laws that is used in the control of the import and export of hazardous wastes. The main laws that are used for implementing Basel are the Environmental Quality Act 1974 (EQA), Environmental Quality (Scheduled Wastes) Regulations 1989, ${ }^{67}$ the Environmental Quality (Prescribed Premises) (Scheduled Wastes Treatment and Disposal Facilities) Order $1989,{ }^{68}$ and the Environmental Quality (Prescribed Premises)(Scheduled Wastes Treatment and Disposal Facilities) Regulations 1989. ${ }^{69}$

The Act and these Regulations work together. Section 34 of the EQA makes it an offence to dump any sort of waste on Malaysian soil or waters, unless it is on specified and licensed premises. It is also an offence to export or import or allow for the transit of hazardous waste without obtaining prior permission from the Director General of the DOE. If the 'consent' is a forgery or is obtained through fraudulent means, this, too, is an offence. These offences carry a maximum fine of RM500,000 and/or a maximum jail sentence of five years.

The Scheduled Wastes Regulations establishes a list of "scheduled wastes". It also establishes the treatments and control of these wastes. The Prescribed Premises Order determines the types of premises that are allowed to handle such wastes and the Prescribed Premises Regulations control the running of these places through a system of licences.

Malaysia is both an exporter and importer of hazardous wastes. Due to a lack of facilities properly to treat or dispose of wastes, exports are made to countries such as the United States, Japan, Singapore, and the United Kingdom. The types of wastes exported are sludge containing heavy metals, spent solvents, spent catalysts and PCBcontaining transformers and capacitors. Conversely, Malaysia imports wastes as raw materials for various industrial processes. Examples include: used lead acid batteries, copper slag and waste plastics. ${ }^{70}$

${ }^{67}$ P.U. (A) $139 / 89$.

${ }_{68}$ P.U. (A) $140 / 89$.

${ }^{69}$ P.U. (A) $141 / 89$.

${ }^{70}$ A.R. Awang and I. Shafii, "Country Report - Malaysia", Proceedings of Regional Seminar on the Implementation of the Basel Convention on the Control of Transboundary Movements of Hazardous Wastes and Their Disposal, Department of the Environment, 11-13 April 1994, Kuala Lumpur. 
Waste exported from Malaysia

$\begin{array}{ll}\text { Year } & \text { Amount (metric tons) } \\ 1993 & 496 \\ 1994 & 1284.1 \\ 1995 & 3734.81 \\ 1996 & 3734.81 \\ 1997 & 2694.04 \\ 1998 & 7161\end{array}$

Most of the wastes are exported to Japan and the United States. Imports of hazardous wastes, on the other hand, are not a common occurrence. The total requests for importation between 1993 and 1998 number 63. The breakdown of the figures is as follows:

Requests for the importation of waste

$\begin{array}{cc}\text { Year } & \text { Requests } \\ 1993 & 13 \\ 1994 & 9 \\ 1995 & 5 \\ 1996 & 8 \\ 1997 & 10 \\ 1998 & 18\end{array}$

To facilitate enforcement and in order to comply with Basel's requirements regarding the import and export of hazardous wastes, two amendments were made to the Orders under the Customs Act $1967 .^{71}$ These were the Customs (Prohibition of Export)(Amendment)(No.2) Order $1993^{72}$ and the Customs (Prohibition of Import)(Amendment)(No.3) Order 1993. ${ }^{73}$

The role of customs officials is to ensure that no export or import of scheduled wastes occurs without the approval of the Director General of the DOE (in the form of the necessary documents). The approval of the DG of the DOE for either imports or exports is dependent on the guidelines ${ }^{74}$ issued by the Department being followed.

In Malaysia the only justification for importing wastes is if it is to be used for the purposes of industry, for example, in the recycling industry. To import scheduled wastes, the importer must fill in the relevant form. The types of information required are: a justification for the importation, and methods of handling the hazardous waste,

71 Laws of Malaysia, Act 235.

72 P.U. (A) 209/93.

73 P.U. (A) $271 / 93$.

${ }^{74}$ Guidelines on the Export, Import and Storage of Scheduled Wastes in Malaysia CD Rom, Department of Environment, Ministry of Science, Technology and the Environment. 
including its collection, packaging, labelling, mode of transportation, and transportation route. This process requires about two months from start to finish. The DOE also examines the environmental impact that such an importation may cause. ${ }^{75}$

The only wastes that can be exported are those that cannot be safely managed (either disposed of or treated) by the facilities in Bukit Nenas, Port Dickson. The necessary forms need to be filled in, and the following information provided: justification for the export; information on the planned methods for the handling of waste, which includes the packaging, and labelling; and the transportation routes (as determined by international law).

The exporter must also provide the written agreements between, firstly, the waste generator and inland waste transporters and, secondly, between the waste generator and recipient. In line with the rules of the PIC there have to be documents, certified true copies, from the competent authority of the receiving country stating that the latter has the facility to dispose of the waste and is competent to do so. A list of all transit countries is also required.

For proper monitoring and accountability purposes, the complete Curriculum Vitae of each of the personnel involved in the export must be submitted. In the event of an accident liability is covered through insurance and bank guarantees. There has to be evidence of both a bank guarantee and an insurance policy before the export can be approved.

\subsection{Problems with Malaysian Basel compliance}

The most obvious problems are the lack of staff and training. The DOE has to deal with fifty to sixty applications for the import and export of hazardous waste per year. It is a lengthy and complex procedure requiring considerable work. One problem is the length of time necessary to obtain answers from importing and transit states. Yet there is in Malaysia only one officer in charge of all Basel business, and even then his duties are not limited only to Basel-related activities.

More serious perhaps is the lack of training amongst customs officers. This is particularly true in cases where expert identification of wastes is necessary. Customs officers face difficulty when identifying wastes. They might mix wastes with actual goods and products, given the nature of some of these wastes. The DOE has provided training for Customs officers, ${ }^{76}$ but the practice of the Royal Customs and Excise is that officers may be transferred from one post to another. Thus, a person who might have obtained training may be posted not to entry points but to Customs Headquarters. This lack of expertise can have serious consequences especially if hazardous waste is not classified as such (thus falling under Art 9(1)(d) of Basel as illegal trade).

75 I. Shafii, "Principles of the Basel Convention", Workshop on Scheduled Wastes Management in Malaysia, Department of Environment, Ministry of Science, Technology and the Environment, Petaling Jaya, Malaysia, 25 July 1995.

76 Awang and Shafii, n. 70. 
As pointed out before, Basel is not just about the control of the transboundary movement of wastes; it is also about the minimization of wastes. In this sense, Malaysia still has a long way to go. The EQA Regulations, for example, have only a rather vague section encouraging the minimization of waste. Therefore, there is no strong legal authority to make sure that this minimization is practised.

Furthermore, industry is given no financial incentive to improve its production methods such that they minimize wastes. The current methods of production and disposal are relatively cheap and it is more economically viable to continue in the present fashion rather than make improvements. The Malaysian Agenda for Waste Reduction programme (MAWAR) conducted by the DOE in the mid 1990s received a very poor response, partly for these reasons.

\section{COMPLIANCE WITH RAMSAR IN MALAYSIA}

The Ramsar Convention is unique in that it requires substantial moves towards compliance before a State can even become a party. In short, a State would have to select a wetland site, based on certain criteria set out in the treaty, to be included in the Ramsar List of Wetlands of International Importance (the List) before it could join (Article 2). This site would then have to be subject to the principle of "wise use" which, in effect, means its protection and care (Articles 3 and 4).

Other obligations include the co-operation and exchange of information with other parties, especially in the case of shared wetlands (Article 5). Member States are also encouraged to substitute the name of another site if they were to remove their selected site from the list (Article 4(2)).

Generally speaking, Ramsar does not comprise detailed law, as CITES and Basel do. The obligations of Ramsar are rather vague; much is left to the individual parties to do what they can. However, despite its seeming simplicity, to comply with the spirit of the treaty is more complex than it would appear. It is in this sense that the Malaysian experience is quite interesting.

The Ramsar site in Malaysia is Tasek Bera. ${ }^{77}$ Tasek Bera is a lake situated in south-west Pahang, a state on the Malaysian peninsula. It is part of an alluvial peat swamp system. It is about twenty-five kilometres from the nearest town, Bahau. The lake has a catchment area of 61,383 hectares, with the southern part of the area being in the state of Negri Sembilan. The catchment area is not pristine, having been exploited for logging and forest conversion (to oil palm cultivation).

Tasek Bera is the largest fresh water lake and swamp system in Malaysia, covering 6,150 hectares. It lies at the centre of the three drainage basins of the Pahang, Rompin and Muar rivers. Tasek Bera was probably formed as a result of changes in the course of the Pahang River and its tributaries, followed by a blocking of the river channel, probably by the plant Rasau. The swamp developed because

77 Information about Tasek Bera is obtained from P. Benstead, C. Jeffs and R. D'Cruz, Tasek Bera: The Wetland Benefits of the Lake System and Recommendations for Management, Asian Wetland Bureau, 1993. 
of the waterlogged environment and consists of three main habitats: peat swamp forest, extensive reed beds, and open water with beds of submerged plants. ${ }^{78}$

The area is rich with plant life that includes Utricularia flexuosa, Lepirironia, ferns, screw pines, orchids and sedges. The fauna are equally impressive. There are ninety-five species of fish, including the endangered Asian Arowana and Ikan Temerloh. Approximately 200 species of birds were recorded. The endangered Crested and Crestless Fireback, Masked Finfoot and the Malaysian Night Heron are among them. Tasek Bera is not, however, an important haven for waterfowl due to the naturally acidic nature of the water.

There is no complete list of mammals in the area, but the following species have been sighted: the Clouded Leopard, Leopard, Tiger, Asian Elephant and the Tapir. All of these species are rare and the Tiger, Tapir and Elephant are endangered.

The legal issue here is that the establishment of a protected site is under the ambit of the regional state government, in this case the Pahang state government. Therefore, the administration of the site lies in its hands. The problem was that the Pahang state government did not have the necessary expertise to devise a management plan for the area. This was overcome by turning to the non-governmental organization (NGO), Wetlands International.

With funding from the Danish Government, Wetlands International set about drawing up a cross-sectoral management plan for the site. There is now in place an administrative and management structure for the protection of the site. The responsible authority for the administration of the site is the Pahang State Director of Forests. However, the Department of Wildlife and National Parks is the lead management agency in view of its conservation remit and the fact that the Ministry of Science, Technology and the Environment is the national administrative authority for the Ramsar Treaty. Other government agencies do play a part by providing their expertise when necessary.

The management authority staff is under the supervision of a Chief Officer, who reports to the Ramsar Management Executive Body - the main policy and decisionmaking body of the system. The Secretary General of the Ministry of Science, Technology and the Environment chairs it. Aiding the Executive Body are two supportive committees: the Scientific Advisory Committee, which provides technical information about the site's management and research activities, and a Consultative Committee chaired by the Pahang State Economic Planning Unit. This Consultative Committee provides a formalized mechanism for consultation with stakeholders and to co-ordinate site management with government planning processes. ${ }^{79}$

In the day-to-day running of the site staff will be seconded from relevant government agencies. These include the Department of Wildlife and National Parks, the Forestry Department, the Fisheries Department, the Department of Environment, the Pahang State Tourism Agency, and the Department for Orang Asli ${ }^{80}$ Affairs. The

78 Integrated Management of Tasek Bera, Support for the Implementation of Obligations under the Ramsar Convention: Project Brief, Wetlands International, at 1.

79 Wetlands International is to sit on both of these committees.

80 Indigenous Peoples. 
Management Authority also has the power to employ local people in roles such as rangers and wardens.

This cross-sectoral management body is to be applauded, as the issues involved in the protection of an eco-system like a wetland are numerous. For example, the presence of the Department of the Environment is potentially useful if the area is faced with the problem of pollution from the oil palm plantations surrounding the Tasek Bera site. Furthermore, the site has now been earmarked to be gazetted under the National Forestry Act 1984 as a Permanent Reserved Forest, thus ensuring that it has special legal protection.

\section{IN SUPPORT OF COMPLIANCE THEORY}

It is submitted that the Malaysian experience supports the ideas in compliance theory. It shows that once a country has agreed to be part of a treaty regime, any non-compliance is not simply a matter of self-interest versus international obligations. Furthermore, the theories as to what encourages compliance also appear to be justified.

First and foremost, there has been much effort made to comply with these treaties. It is illogical to believe that States would take the trouble and the effort to be part of a treaty regime only not to comply. This is particularly true with treaties in which States believe. What can also be seen from this case study is that treaties that are properly formulated, with clear goals, objectives and methods of achieving them, are more likely than not to experience compliance. It is impossible to be part of CITES without the establishment of a Management and Scientific Authority; it is impossible to be part of Basel without clear laws against illegal traffic, and it is impossible to be part of Ramsar without having first chosen a site to be placed on the List.

Once the institutions and mechanisms are put into place, compliance has a tendency to become habit-forming. The 'way things are done' becomes compliance with the treaty. It then becomes a matter of following the set procedure in order to comply. If Malaysia were to make a decision based on economic and/or military considerations each time the government is faced with a choice whether to allow import or export of hazardous wastes, it would be a time-consuming and laborious exercise of constantly weighing the pros and cons of such an application. It is far easier merely to allow the mechanisms in place to do the decision-making. In other words, the Realist argument that self-interest comes first all the time is in reality not practical.

What this case study also shows is that the problems faced by Malaysia in complying with the three Treaties discussed above are rather about capacity than recalcitrance. The lack of expertise and training arise time and again. With regard to CITES the poor baseline data on species make it hard for a Scientific Authority, the ad hoc body that it is, to make truly sound decisions. In both CITES and Basel implementation, the lack of training amongst front-line officers, particularly customs officers, means that border checks are not as sound as they should be. 
These types of problems do not lead to non-compliance per se, but together are perhaps better described as 'poor' compliance. The encouraging factor is, however, that these are not insurmountable problems. One way around difficulties of this sort is, of course, for the regime itself to provide help. This can be in monetary form or even in the form of training. The CITES Secretariat, for example, does provide seminars for the identification of species. However, these seminars could benefit from being more specific to the needs of individual nations.

The way that Ramsar was implemented in Malaysia provides an interesting solution. The Pahang State Government entrusted with the management of the Ramsar site was not well equipped to do the job. Therefore, help was obtained through two methods: funds were obtained through a Danish Aid Programme, and Wetlands International, an NGO, provided the expertise. It is this sort of imaginative problemsolving solution that perhaps environmental treaty regimes should explore further.

It is submitted as well that treaties with a sound reporting mechanism and good transparency encourage compliance. They take the form of obligating regular reports, frequent Conferences of Parties that are open to as many parties as possible, and an active secretariat. All three treaties studied have these mechanisms in place and result in greater consideration of compliance on the part of the Malaysian government.

The argument used is that with greater transparency, the 'good' states can be recognized and 'bad' States shamed. This is true because without transparency and public criticism, then non-compliance would go "unpunished". However, there is another aspect to transparency: the human factor.

During the course of the interviews conducted, there was an interesting incident where the officer being questioned expressed embarrassment that the country report that should have been prepared by his department was not yet ready. This desire to do a job well in the light of international scrutiny can also be seen in the frantic activity currently being experienced in the Ministry of Science, Technology and the Environment regarding wetlands. The Ramsar Conference of Parties in Seville in 2002 provided a spur for the Ministry and its officials to take more pro-active measures for wetland protection. These include the urgent implementation of the Malaysian Wetland Policy and the search for more sites to add to the Ramsar List. ${ }^{81}$

\section{CONCLUSION}

In conclusion, it is submitted that the theories put forward by the likes of Chayes and Chayes, Mitchell, and Brown Weiss and Jacobson ring true. The reasons for compliance and non-compliance are not a simple matter of States being 'bad' and 'selfish'. Taking such a cynical stand would lead to the conclusion that either it was not worth the effort to try to improve compliance or to believe that the only way to improve compliance was through purely political means, with economic and military sanctions as enforcement measures.

${ }^{81}$ Three more sites have now been earmarked as Malaysian Ramsar sites. 
Yet from what has been discussed, it has been shown that compliance either happens or does not happen for a variety of complex reasons, and not all of them can simply be explained away as a matter of self-interest. Therefore, environmental treaty regimes would do well to take into consideration these complex factors, which include the form of the treaty, the methods through which to achieve the objectives of the treaty, and the capacity of the parties, when determining how to improve compliance.

To summarize, if a treaty is to succeed, then it should have the following characteristics: the treaty-making process should be as democratic as possible, with all interested parties being able to participate in a meaningful way towards the formation of the treaty; the treaty itself should be clear, and the obligations imposed should be made as clear and as definite as possible. If compliance can be obtained through bureaucratic methods, such an approach should be encouraged, because bureaucracies are habit-forming.

Treaty regimes must either make aid (financial and practical) available to poorer members, or the latter should be imaginative in their approach to obtaining the said help. While the Secretariat may not have unlimited wealth, it should have enough funds to be as pro-active as possible, establishing close ties with the relevant officers, being sensitive and quick to respond to any changes or to any requirements of treaty members. However, this help must be dictated by the needs of the parties. Expert advice and training would be really helpful only if they were directed to the places in greatest need.

Transparency and inclusiveness should be of paramount priority. Reporting on a regular basis is a must (along with the necessary help, if so required), as are regular Conferences of Parties. Non-governmental bodies should be as involved as closely as possible in the entire regime, from its formation to its implementation. This is not just for the usual reasons of the existence of such groups: playing watchdog and public decriers of foul play; NGOs can also be vital on the ground, either in helping enforcement bodies by being an extra pair of eyes (as TRAFFIC, the wildlife trade NGO, is to PERHILITAN) or even by helping governmental agencies ill-equipped to do the work at hand (as Wetlands International is to the Pahang State Government).

Finally, what must not be forgotten is the human factor. PERHILITAN have been attempting for years to change legislation in order for CITES species automatically to be included in the Protection of Wildlife protected species lists. The Legal Adviser for the department was closely involved in the process which, until recently, seemed as though it would become a reality. However, recent administrative changes saw the Legal Adviser leaving PERHILITAN, to be replaced by another officer who reportedly does not have the same enthusiasm for the project, thus leaving it stalled.

It is submitted that such an occurrence illustrates the overlooked fact that governments and government agencies are not faceless entities; they consist of real men and women, who behave in a myriad of ways. No international document, no matter how well crafted, can change this fact. Yet this human factor cannot and must not be overlooked. People can make a difference; how they do their duty is one such way that this can be achieved - nor can we forget the power of the public in pushing 
their governments towards positive action. Compliance ultimately lies therefore in the hands of the people; those with the duty to their jobs, and those who care enough to make sure the jobs are done well. 